\title{
Sensitivity analysis of restricted orifice in the hydropower station
}

\author{
X.F. DIAO, X.H.ZHANG\&Y.Y.YANG \\ Xi'an University of Technology, Xi'an, Shaanxi, China
}

\begin{abstract}
KEYWORD: Restricted orifice surge chamber; Sensitivity analysis; Surge level; Hydraulic disturbance

ABSTRACT: The overflowing property of the restricted orifice how to affect volute pressure and the surge level under the condition of large fluctuation and the output swing of the unit under the condition of the hydraulic disturbance were studied. Combining with the engineering features of three adits sharing surge chamber, use general-purpose software to compute for the restricted orifice surge chamber project example. The sensitivity analysis shows that the flow status of restricted orifice is better while its diameter is $3.5 \mathrm{~m}$ and height is $8.25 \mathrm{~m}$, calculation of guaranteed regulation and surge level can also meet the requirements.
\end{abstract}

\section{INTRODUCTION}

In the construction of hydropower stations, different types of surge chamber are set up according to the actual need of the project to reduce water hammer pressure of the diversion system, so that the operating conditions of the unit can be improved. Restricted orifice surge chamber is connected with the tunnel and pressure pipes by a small cross-section hole, so there is energy loss at the restricted orifice and an accelerating trend in surge level fluctuations decay. The restricted orifice surge chamber has been widely used in the project for having smaller volume than the simple surge chamber (Liu \& Hu 2010, Zhang \& Miao 2012, Chen \& Zhang 2015). However, water hammer can not be fully reflected in the tunnel due to the impedance, which may affect the flow state. Selecting the appropriate area of restricted orifice is really important (Chen \& Yang 2014, Wang \& Yang 2015). In this paper, different flow coefficients were combined with various restricted orifice area to determine the appropriate orifice size by sensitivity analysis, which can be referenced by other projects.

\section{PROJECT OVERVIEW}

The hydroelectric power station located in Bailong River Wen County Gansu Province is a largescale water conservancy project, which is mainly used to generate electricity and also has other comprehensive benefits. The station installed capacity is $3 \times 10$ million kilowatts. The buildings on the left bank include the power diversion intake, the headrace tunnel, the bifurcated pipe, the surge chamber and the pressure pipe. The main diversion tunnel is $356.1 \mathrm{~m}$ long with a diameter of 10.5 $\mathrm{m}$. Three pressure pipes with a diameter of $6 \mathrm{~m}$ are led from surge chamber. The type of the turbine is HL702-LJ-410 and the rated speed is $150 \mathrm{r} / \mathrm{min}$. Design head is $73 \mathrm{~m}$, the maximum head is 89.2 $\mathrm{m}$, and the minimum head is $57.5 \mathrm{~m}$.

\section{SENSITIVITY ANALYSIS}

\section{Overflowing Property of the Restricted Orifice}

Design code for surge chamber (SL655-2014 2014) suggests that the area of the restricted orifice is $25 \%$ to $45 \%$ of the cross-section of the pressure conduit or pressure tail tunnel. When it is less than $25 \%$, the pressure of the end of the penstock and the bottom of surge chamber will have a sharp deterioration. When it is greater than $45 \%$, the inhibition of fluctuations and accelerating attenuation are not obvious. The code also suggests that the restricted orifice flow coefficient can be selected from 0.60 to 0.80 at the beginning of calculation. Therefore, restricted orifice diameters are set as $3.0 \mathrm{~m}, 3.5 \mathrm{~m}$ and $4.0 \mathrm{~m}$ and flow coefficients are $0.65,0.70$ and 0.75 . Three different restricted orifice areas and flow coefficients are combined. The results are shown in Table 1. 
Table 1 Sensitivity analysis of flow coefficient and restricted orifice area

\begin{tabular}{|c|c|c|c|c|c|c|c|}
\hline \multirow[t]{2}{*}{ Condition } & \multirow{2}{*}{$\begin{array}{l}\text { Flow } \\
\text { coefficient } \\
\varphi\end{array}$} & \multirow{2}{*}{$\begin{array}{l}\text { Restricted } \\
\text { orifice } \\
\text { diameter } / \mathrm{m}\end{array}$} & \multirow{2}{*}{$\begin{array}{l}\text { Maximum of } \\
\text { volute end } \\
\text { pressure } / \mathrm{mH}_{2} \mathrm{O}\end{array}$} & \multicolumn{2}{|c|}{$\begin{array}{l}\text { Impedance board } \\
\text { pressure } / \mathrm{mH}_{2} \mathrm{O}\end{array}$} & \multicolumn{2}{|c|}{ Surge level $/ \mathrm{mH}_{2} \mathrm{O}$} \\
\hline & & & & Down & Up & Max & Min \\
\hline A1 & 0.65 & 3.0 & 123.13 & 8.44 & 17.86 & 714.56 & 706.29 \\
\hline A2 & 0.65 & 3.5 & 119.79 & 8.03 & 14.06 & 716.64 & 705.11 \\
\hline A3 & 0.65 & 4.0 & 118.9 & 7.30 & 10.58 & 718.47 & 703.66 \\
\hline B1 & 0.70 & 3.0 & 122.55 & 8.36 & 17.01 & 715.05 & 706.05 \\
\hline B2 & 0.70 & 3.5 & 119.48 & 7.88 & 13.07 & 717.16 & 704.75 \\
\hline B3 & 0.70 & 4.0 & 118.79 & 7.02 & 9.66 & 718.95 & 703.20 \\
\hline C1 & 0.75 & 3.0 & 121.94 & 8.29 & 16.17 & 715.51 & 705.81 \\
\hline $\mathrm{C} 2$ & 0.75 & 3.5 & 119.11 & 7.70 & 12.16 & 717.43 & 704.38 \\
\hline C3 & 0.75 & 4.0 & 118.71 & 6.73 & 8.82 & 719.39 & 702.74 \\
\hline
\end{tabular}

Effects on large fluctuation transition process

The typical condition of large fluctuation transition process is that three units are all in condition of full load rejection at the same time when the upstream is in the check flood level and pipes take the minimum value of roughness coefficient $\left(\mathrm{GD}^{2}=17500 \mathrm{t} \cdot \mathrm{m}^{2}\right.$, surge chamber area is $380.16 \mathrm{~m}^{2}$, taking 10s broken-line shut mode). Results of sensitivity analysis are shown in Table 1.

According to the Table 1, when the flow coefficient of the restricted orifice is constant, the larger restricted orifice area is the less pressure the end of volute and impedance board will take and the highest up surge level increase to a certain extent is. After analyzing the rise process of volute pressure, it can be found that when the area or flow coefficient of restricted orifice is too small, the volute pressure rises higher because of insufficient water hammer wave reflection and the maximum volute pressure is mainly affected by water hammer pressure; on the contrary, the rising of the volute pressure is mainly caused by the highest up surge level. When the restricted orifice diameter is $3.0 \mathrm{~m}$ and flow coefficient is 0.65 , the maximum volute pressure reaches $123.13 \mathrm{mH}_{2} \mathrm{O}$, which exceeds $2.61 \%$ of the design control index; when the restricted orifice diameter is $4.0 \mathrm{~m}$ with the flow coefficient set as any value, the maximum surge is higher than the operating room (718.5 $\mathrm{m})$. When the restricted orifice diameter is set as $3.5 \mathrm{~m}$, the indicators meet the design requirements under the typical conditions, so the restricted orifice diameter is taken $3.5 \mathrm{~m}$. Detailed parameters are shown in Figure 1 and Figure 2.

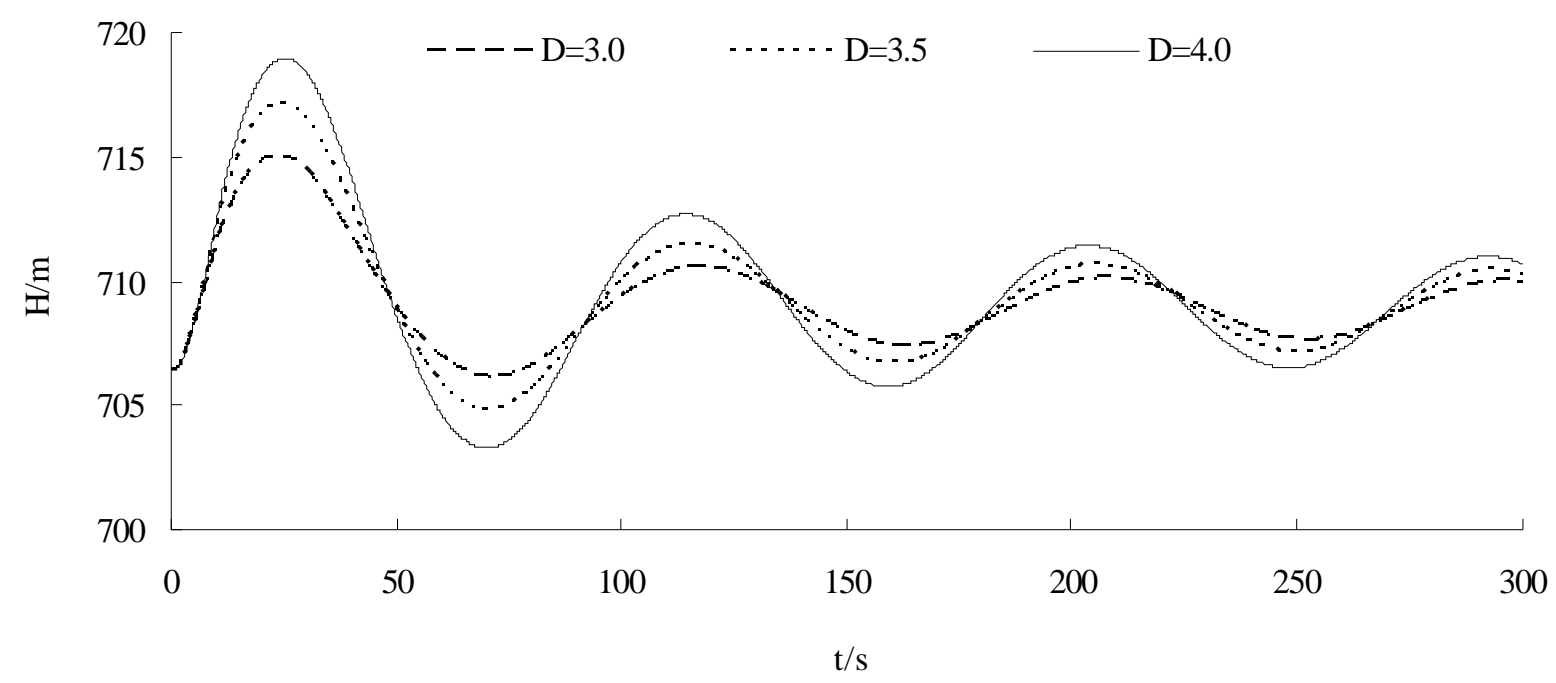

Figure 1. Surge level process line at 0.7 coefficient 


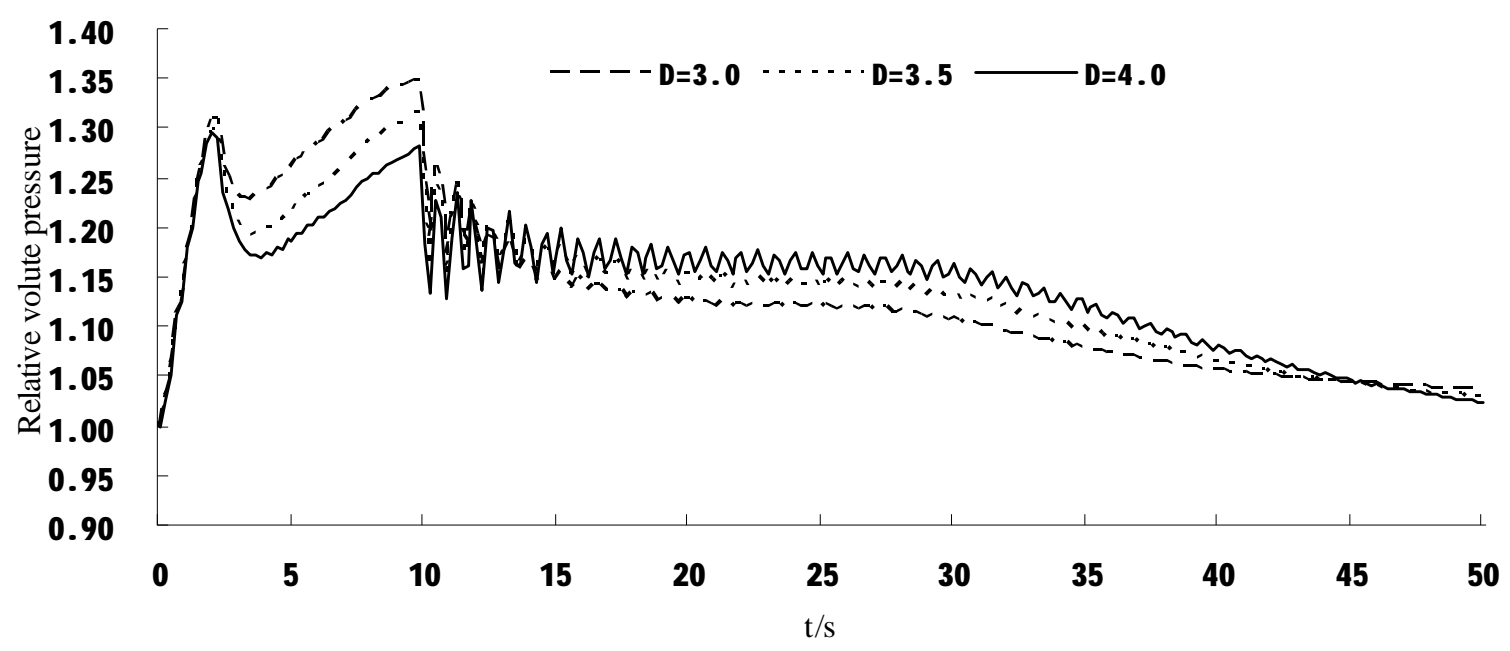

Figure 2. The volute pressure process line of $1 \#$ unit $(\varphi=0.7)$

\section{Effects on hydraulic disturbance transient process}

Three adits share surge chamber in this power station. As a result, load changes in anyone of the three units (or two) will affect the running of the other two(or one) by the fluctuation of surge chamber, which is called hydraulic disturbance (Yue \& Li 2015, Wu \& Zhou 2015). Under the circumstance of typical hydraulic disturbance, where one (or two) unit is in condition of load rejection while the others are in normal running when the upstream is at the rated head and the pipes take average value of roughness coefficient $\left(\mathrm{GD}^{2}=17500 \mathrm{t} \cdot \mathrm{m}^{2}\right.$, surge chamber area is $380.16 \mathrm{~m}^{2}$, taking 10s broken-line shut mode), calculation results are shown in Table 2. Hydraulic Disturbance mainly reflects in the output swing, calculation results are shown in Table 2.

As shown in Table 2, no matter the unit is incorporated into the infinite power grid or the isolated grid, while the flow coefficient is constant, the smaller the restricted orifice area is, the greater output swing of the disturbed unit will be, but the output swing of two units disturbed by the other one load rejection is really small. As the restricted orifice area is bigger, the output swing of the unit disturbed by the other two load rejection gets improved apparently in turn. The output swing of the unit incorporated into the isolated grid is smaller than into the infinite power grid under the same condition. Figure 3 shows that regardless of the unit is incorporated into an infinite power grid or an isolated grid, the smaller the restricted orifice area is, the sooner the largest output time appears. 
Table 2 Summary on calculations for hydraulic disturbance conditions

\begin{tabular}{|c|c|c|c|c|c|c|c|c|}
\hline \multirow[b]{2}{*}{ Condition } & \multicolumn{4}{|c|}{ Incorporated into the infinite power gid/MW } & \multicolumn{4}{|c|}{ Incorporated into the isolated power grid/MW } \\
\hline & $\begin{array}{l}2 \neq \text { load } \\
\text { rejection } \\
\text { maximum } \\
\text { output of } \\
1 \neq\end{array}$ & $\begin{array}{l}\text { Swing of } \\
\text { output } / \%\end{array}$ & $\begin{array}{l}1 \neq 、 3=\text { load } \\
\text { rejection } \\
\text { maximum } \\
\text { output of } \\
2 \neq\end{array}$ & $\begin{array}{l}\text { Swing of } \\
\text { output } \%\end{array}$ & $\begin{array}{l}2 \neq \text { load } \\
\text { rejection } \\
\text { maximum } \\
\text { output of } \\
1 \neq\end{array}$ & $\begin{array}{l}\text { Swing of } \\
\text { output } \%\end{array}$ & $\begin{array}{l}1 \neq 、 3=\text { load } \\
\text { rejection } \\
\text { maximum } \\
\text { output of } \\
2 \neq\end{array}$ & $\begin{array}{l}\text { Swing of } \\
\text { output } \%\end{array}$ \\
\hline A1 & 114.83 & 11.11 & 125.17 & 21.11 & 110.17 & 6.60 & 114.05 & 10.35 \\
\hline $\mathrm{A} 2$ & 114.79 & 11.06 & 121.71 & 17.76 & 109.56 & 6.00 & 111.63 & 8.01 \\
\hline $\begin{array}{l}\text { Relative } \\
\text { difference/ } \\
\%\end{array}$ & 0.04 & & 3.35 & & 0.59 & & 2.34 & \\
\hline B1 & 114.82 & 11.10 & 124.32 & 20.30 & 110.63 & 7.04 & 113.49 & 9.81 \\
\hline B2 & 114.80 & 11.08 & 120.98 & 17.06 & 109.78 & 6.22 & 110.74 & 7.15 \\
\hline $\begin{array}{l}\text { Relative } \\
\text { difference/ } \\
\%\end{array}$ & 0.02 & & 3.23 & & 0.82 & & 2.66 & \\
\hline $\mathrm{C} 1$ & 114.83 & 11.11 & 123.54 & 19.54 & 111.06 & 7.46 & 112.96 & 9.30 \\
\hline $\mathrm{C} 2$ & 114.80 & 11.08 & 120.45 & 16.55 & 110.05 & 6.48 & 110.05 & 6.48 \\
\hline $\begin{array}{l}\text { Relative } \\
\text { difference/ } \\
\%\end{array}$ & 0.03 & & 2.99 & & 0.98 & & 2.82 & \\
\hline
\end{tabular}

*1. Initial output is $103.35 \mathrm{MW}$;

2. Relative difference $=$ difference $/$ Initial output.

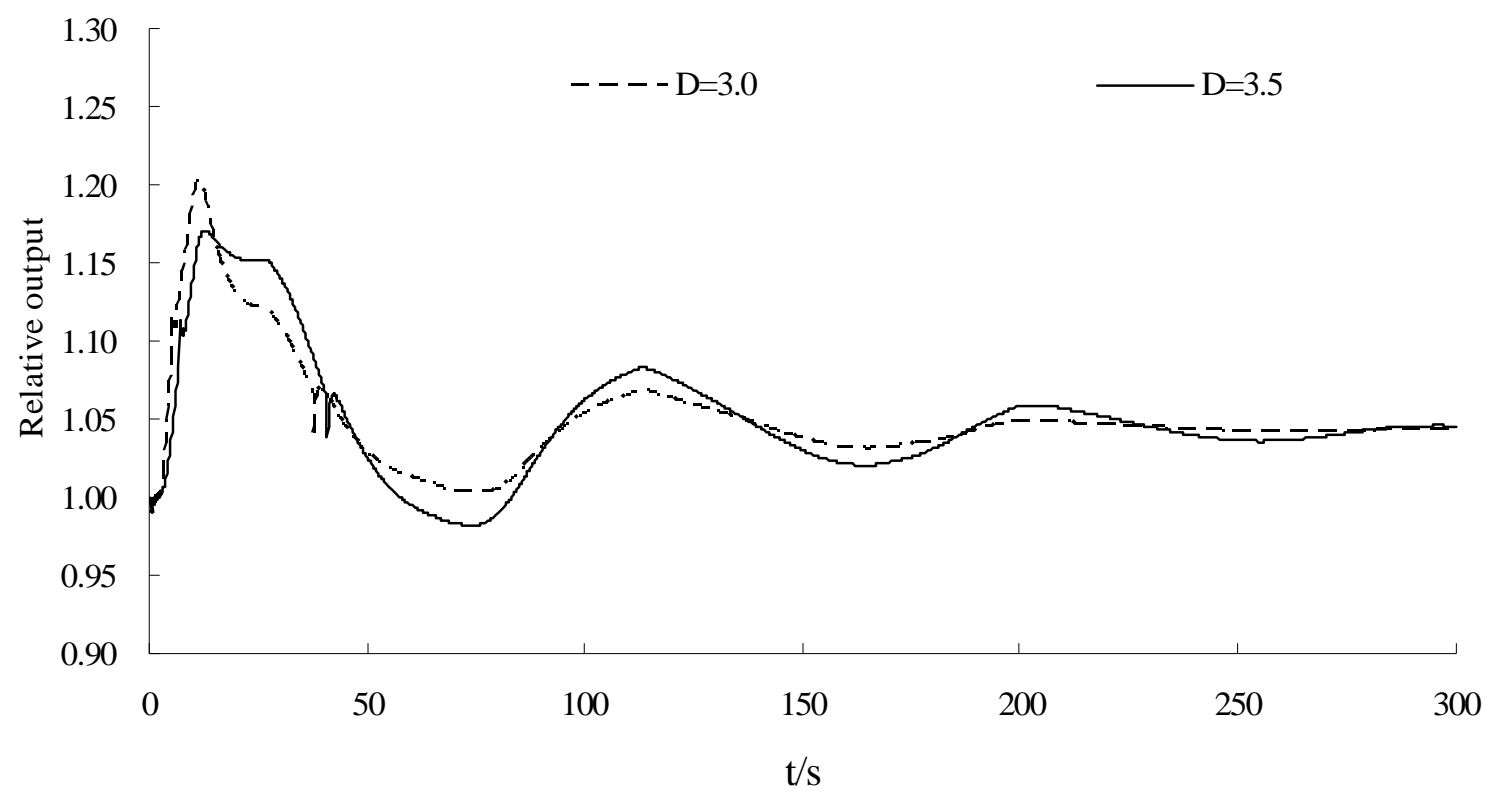

(a) Incorporated into the infinite power grid 


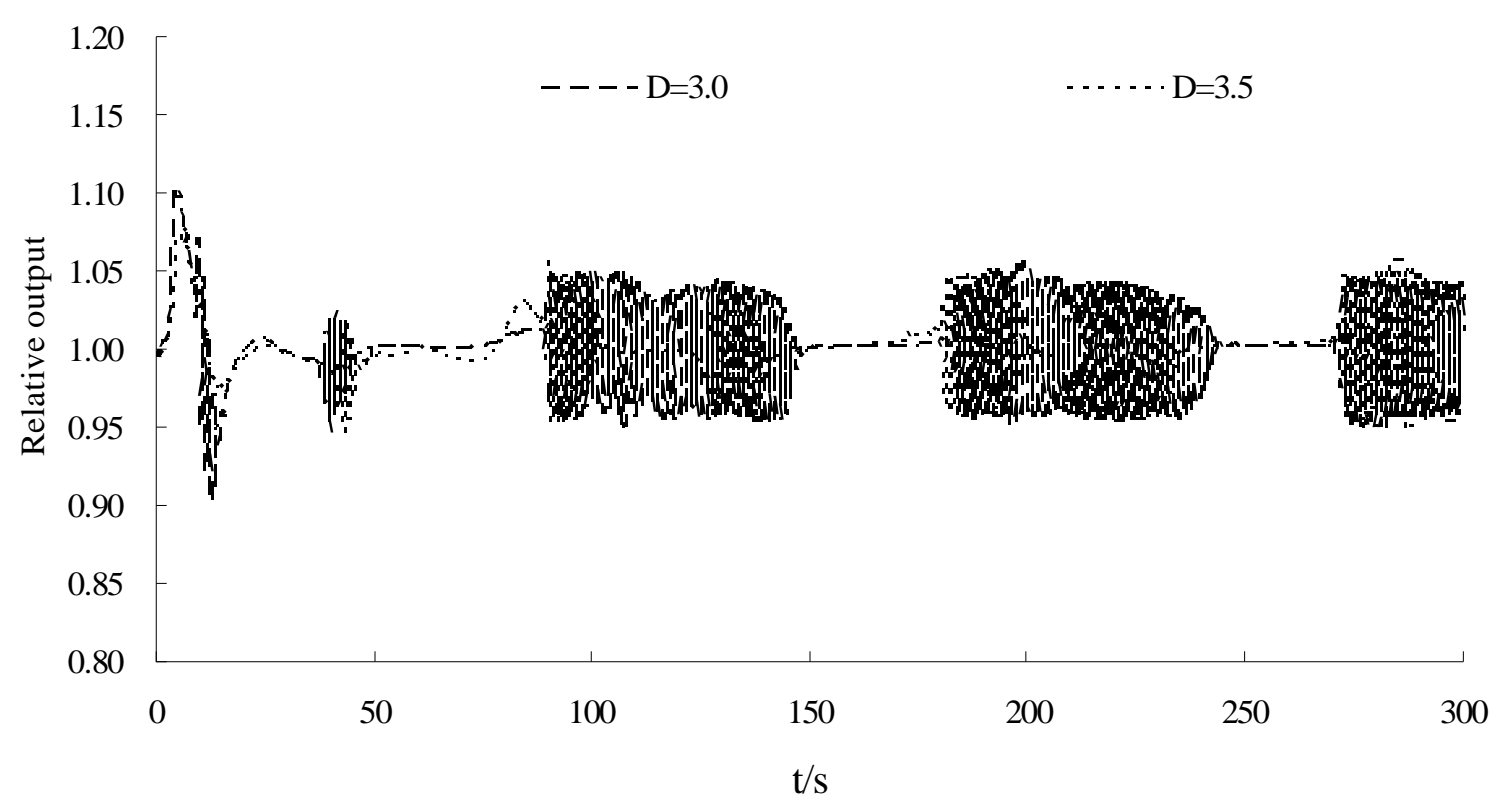

(b)Incorporated into the isolated power grid

Figure 3. The output process line of $2 \#$ unit $(\varphi=0.7)$

Table 3 Sensitivity analysis of the restricted orifice height

\begin{tabular}{|c|c|c|c|c|c|c|}
\hline \multirow{2}{*}{ Condition } & \multirow{2}{*}{$\begin{array}{l}\text { Maximum } \\
\text { rotating speed } \\
\text { increases } \\
\text { rate } \%\end{array}$} & \multirow{2}{*}{$\begin{array}{l}\text { Maximum of } \\
\text { volute end } \\
\text { pressure } / \mathrm{mH}_{2} \mathrm{O}\end{array}$} & \multicolumn{2}{|c|}{ Impedance board pressure $/ \mathrm{mH}_{2} \mathrm{O}$} & \multicolumn{2}{|c|}{ Surge level $/ \mathrm{mH}_{2} \mathrm{O}$} \\
\hline & & & Down & Up & Max & Min \\
\hline$J-2 \mathrm{~m}$ & 33.89 & 119.46 & 5.92 & 13.84 & 716.93 & 704.51 \\
\hline$J-6 m$ & 33.90 & 119.48 & 5.58 & 13.31 & 717.09 & 704.68 \\
\hline $\mathrm{J}-10 \mathrm{~m}$ & 33.90 & 119.48 & 5.18 & 12.97 & 717.20 & 704.80 \\
\hline $\mathrm{D}-2 \mathrm{~m}$ & 26.52 & 93.48 & 4.09 & 11.01 & 693.19 & 681.19 \\
\hline D- $6 \mathrm{~m}$ & 26.52 & 93.50 & 3.77 & 10.94 & 693.19 & 681.19 \\
\hline D-10m & 26.52 & 93.49 & 3.57 & 10.95 & 693.19 & 681.19 \\
\hline
\end{tabular}

Sensitivity analysis of the height of the restricted orifice

In conventional restricted orifice surge chamber, the head loss of the surge chamber is mainly composed of two parts, one is the local head loss caused by the orifice contraction, and the other is the sudden expansion of the section after flowing out of the orifice, the flow coefficient can be approximated by the orifice's. Therefore the height of the restricted orifice is set as $2 \mathrm{~m}, 6 \mathrm{~m}$ and 10 $\mathrm{m}$ for comparison. Condition $\mathrm{J}$ is that three units are in condition of full load rejection at the same time when the upstream is in check flood level and pipes take the minimum value of roughness coefficient. Condition D is that when the upstream is in dead storage level and the others is the same as Condition $\mathrm{J}$, secondary surge amplitude is concerned in the testing. The sensitivity analysis results are illustrated in Table 3.

When the cross-sectional area of surge chamber is much larger than the restricted orifice's and the distance between the axis of the orifice and the adjacent wall surface is three times larger than the diameter of the orifice, the flow coefficient of water inflow and outflow of surge chamber is substantially constant, the changes in the restricted orifice height have a really small impact on the impedance board pressure, the guaranteed calculation for regulation and surge level.

\section{CONCLUSIONS}

The selection of the restricted orifice is very important in engineering applications. It is essential to consider that not only the flow coefficient range to meet the request of the volute end pressure, 
speed increases and the surge level but also the hydraulic disturbance of the same hydraulic unit should be considered. When the orifice is perfect contraction, the changes in the height of the restricted orifice bring a small impact on the impedance board pressure, the guaranteed calculation for regulation and surge level. Therefore, in order to minimize the amount of engineering, the appropriate height in the actual project should be taken.

\section{REFERENCES}

1.Liu, Q.Z \& Hu, M. 2010. Hydropower Station(The Fourth Edition). Beijing: China Water\&Power Press.

2.Zhang, Y.L \& Miao, M.F. 2012. Explicit formulas for calculating surges in throttled surge chamber. Journal of Hydraulic Engineering43(4):467 472.

3.Chen, S \& Zhang, J. 2015. Surge superposition following successive load rejection in hydropower stations. Journal of Hydraulic Engineering46(11).

4.Chen, J \& Yang, X.L. 2014. Discharge coefficients and local head losses of impedance surge tanks with standpipe. Water Resources and Power32(11): 164 167.

5.Wang, C \& Yang, J.D. 2015. Effect of lateral pipe length of surge tank on its stable section area and regulation quality. Journal of Hydroelectric Engineering 34(1): 93 98.

6.SL655-2014. 2014. Design code for surge chamber of hydropower stations. Beijing: China Water\&Power Press,.

7.Yue, X.S \& Li, G. 2015. Study and prediction of hydraulic disturbance test of Xianyou pumped storage power station. Yangtze River 46(18): 83 85。

8.Wu, S.Y \& Zhou, J.F. 2015. Study on check computation of complicated hydraulic transients in super-long water diversion and power generation system of Jinping II hydropower station. Journal of Hydroelectric Engineering34(1). 